\title{
The nexus between infrastructure and economic development in Ilorin metropolis
}

\section{DOI: http://doi.org/10.26758/9.1.9}

Olayinka Toyin TEJIDEEN (1), Khalid Olatunji RAJI (1), Habib ABDULLAHI (1), Sunday Joseph AKOR (1)

(1) Department of Sociology, University of Ilorin, Nigeria

Address correspondence to: Raji Khalid Olatunji, Department of Sociology, University of Ilorin, Kwara State, Nigeria, Ph.: +23-480-650-598-86; E-mail: rajikhalid90@gmail.com

\begin{abstract}
Objective. The current level of infrastructural development in Nigeria is heartbreaking one. Journeying through the streets of Ilorin, one can see the derelict state of infrastructures. Previous studies have indicated the relevance of infrastructure in driving economic development. The study therefore sought to determine the relationship between the some infrastructure system elements, such as state of the railway system correlated to its level of use, the latter being an indicator of economic development. The study also determined the relationship between the state of hydroelectric power supply and presence of industries, respectively community literacy level and gender equality in the employment of teachers.

Material and methods. The utilitarian theory was employed to explain the area of interest. The study adopted a mixed method of design, utilizing both questionnaire and in-depth interview for data collection. A sample of 262 respondents was drawn from the population with the use of purposive sampling technique. The chi square statistical technique was used to test the quantitative data.

Results. State of railway transport system is significantly associated to its level of use by people of Ilorin $\left[\mathrm{C}^{2}(6, \mathrm{~N}=250)=85.214, \mathrm{p}=.05\right]$. State of hydroelectric power supply is significantly associated to the presence of industries in Ilorin metropolis $\left[\mathrm{C}^{2}(6, \mathrm{~N}=250)=102.865, \mathrm{p}=.05\right]$. Community literacy level is significantly associated to level of gender equality in the employment of teachers in Ilorin metropolis $\left[\mathrm{C}^{2}(4, \mathrm{~N}=250)=84.112, \mathrm{p}=.05\right]$. The findings from the in-depth interview corroborate those results.

Conclusions. The three hypotheses tested revealed a significant association between the variables of study. With this result in mind, it is recommended that efforts should be made by Kwara state government to strive rendering infrastructural facilities available to the inhabitants of Ilorin metropolis in order to achieve the desired development.
\end{abstract}

Keywords: infrastructure, economic, development, poverty, metropolis.

\section{Introduction}

Economic development epitomizes a chief objective of most of the world's nations. It remains the most critical social task facing nations of the world as they become saddled with the responsibility to raise the well-being and socio-economic conditions of people.'The access to habitation is a complex phenomenon which does not involve just the simple fact of owning or living in a habitation. It is a human fundamental need for both shelter and access to utilities and basic services. The right to habitation is a fundamental human right, explicitly or implicitly". Rada showed the rural/urban disparities in Romania regarding infrastructure, connection to the 
drinking water network, sewerage network (Rada, 2013, p. 336). The present study shows that some localities (such as Ilorin), although they are declared cities, have a rural infrastructure.

Essentially, researchers and policy makers have recognized the critical relevance of efficient infrastructure to the sustainable economic development of a nation (Aschauer, 2000). Accordingly, adequate provision of infrastructure supports economic growth, enhances value of life and is vital for national security (Baldwin and Dixon, 2008). The primal significance of infrastructure is made clearer by pointing out that it includes the whole range of services such as railways, roads, education, telecommunication, shipping, power generation and transmission, urban development, and postal facilities. For instance, better roads decrease accidents and improve public wellbeing, efficient water systems reduce the level of disease infections, and a proper waste management improves aesthetics as well as the health of communal members. The availability of a decent level of these infrastructures stimulates rapid industrialization, improving the quality of life of people (Gibson and Rozelle, 2003). As such, social infrastructures are basically the wheels of development, the absence of which cripples the economy (Edun, 2011).

Notably, there are tangible indications that poor infrastructure hampers development in many ways. Diao and Yanoma (2003) showed that growth in agriculture is constrained by high marketing costs due to poor transport facilities. In addition, a poor educational infrastructure system would rob a society of improving the literacy level among the populace, consequently reducing their intellectual prowess. Estache and Vagliasindi (2007) further argued that insufficient power generation confines the development of a nation. Energy is such a critical factor of development, often serving as an input for other infrastructural systems (such as water system which cannot be made available without the use of electricity).

Developing nations like Nigeria typically lack basic infrastructure such as potable water and, to a lesser extent, a good transport system (Estache and Vagliasindi, 2007). According to Bakare (2006), the provision of basic infrastructure seems to be a herculean task for most state governments in Nigeria. They drink, bathe, and cook with unhygienic water especially in the rural areas, often resulting in serious illness or death, reducing the nation's labour force. On another note, a deficiency in transport system in some parts of Nigeria results in scenarios whereby traffic and passenger congestion is quite rampant, impeding the flow of commercial activities (Edun, 2011). Massive gridlocks are common in the large cities with the resultant effect of delays in movements and accidents. This perilous situation has serious impact over the economic development and it constitutes a major setback in the pursuit of sustainable development in Nigeria.

In spite of the various attempts by government to provide infrastructures, there is no major headway being made, making it a losing battle as days go by In line with the stated problem, the study provides an outlook on the association between infrastructure and economic development in Ilorin metropolis by studying specific types of infrastructure (such as hydroelectric power supply) that have been rarely explored in Nigeria. The study examines the association between steady power supply and industrial development as well as the nexus between societal educational level and human capital development in the study area.

Infrastructures essentially comprise of physical edifices of various types, employed by various industries as inputs to the production of goods and provision of services (Chan et al, 2009). This portrayal encompasses social infrastructure such as hospitals and schools as well as economic infrastructure consisting of energy, water, transport, and digital communications. The sector includes a wide range of services such as roads, airways, railways and water transport services, power generation, telecommunications, port handling facilities, water supply and sewage disposal, mass transport systems, medical facilities, educational facilities and other primary services.

Essentially, Shah (1969) has classified these under eight different headings such as irrigation, power, transport, education, communication, research and development, health and 
other facilities comprising of law and order as part of infrastructure. A very comprehensive depiction of the components of infrastructure is examined in the analysis delivered by Rao (1968). According to him, the economic infrastructure comprises of the transportation (roads, railways, shipping ports and harbors, airports, and transport equipment); communication (telegraphs, telephones, radio, television, cinema, etc.); and energy/power system (coal, electricity, wind power, solar energy, oil, gas, and bio-gas).

Chambers (2004) contends that development has been seen to connote various things at various times, in varying places, and by various people in differing occupations and organizations. But in all cases, it has always involved discussions about change. Economic development therefore represents a course from a lower to a greater phase with an element of visible change. Blakely (1989) on the other hand outlines economic development to be a process through which the government manages prevailing resources and enters into partnership with the private sector, or with another nation, to generate new jobs as well as to rouse economic activities. The quantity of the new jobs is a measure of economic development that has been employed to assess the efficacy of development programs.

There has always been a great interest from the researchers, policy makers as well as non-government organizations on how to measure economic development. The basic needs approach stresses six areas in terms of the achievement of economic development; basic education, sanitation, health, water supply, housing, and nutrition (Hicks and Streeten, 1979).To Harbison and Myres (1964), index of 'Social Progress' comprises of more than forty indices which are found under ten sub-divisions; health status, efforts at defense, environment, status of women, education, demography, social chaos, cultural diversity, economic, and welfare effort (Camp and Speidel, 1987). Finally, in the work of Anand and Sen (1994), development should be seen in terms of attainments in three scopes: health, living standards and education.

Van der Gaag (2011) stated than the indices of economic development entail higher education and literacy levels, general improvement in health as well as nutrition, high social skills, social cohesion and improved levels of equality. In the view of Henderson (1994), environmental indices should also be discussed. Lately, sustainable economic development is the desire of all nations, being measured by the extent to which developmental efforts mustered in the present do not endanger the posterity. It takes the long term interest in mind rather than short term. Gilbert et al. (1996) devised a concept in relation to sustainable economic development, which is economic sustainability. This addresses the country's financial feasibility with development geared to the sustenance of the environment. Furthermore, development economists have cited the relevance of modern transportation in measuring economic development.

In a bid to draw out a connection between infrastructure and economic development, a systematic review of some studies was presented. Starting with that of Antle in Uwagboe (2011), a study was done in 47 developing nations and 19 developed nations. Antle discovered that transportation infrastructure was an effective factor influencing economic development. However, the significance of electricity to economic development has been globally well documented in a huge amount of studies as it is more or less a recurrent point in all investigations on the obstructions to the business environment (Dethier, Hirn and Straub, 2008). Amid these researches, all those concentrating on developing nations discover a significant impact of the energy infrastructure on economic development. As a matter of fact, while carrying out his survey, Garsous (2012) contends that studies concentrating on the energy sector are more probable to discover a significant positive effect than other infrastructures, all things being equal. This implies that investment in the energy sector might be the best bet to attain economic development. Adenikinju (2005) delivered a robust argument to back the relevance of electricity supply. The poor nature of electricity supply in Nigeria, according to him, has weighed on the industrial sector of the country, which is the driver of economic development. 
But despite a general agreement among researchers on the perceived relevance of energy to economic development, there have been debates over some infrastructures, such as the water infrastructure. Mixed conclusions have been reached by researchers in this aspect. Binswanger, Khandker and Rosenzweig (1993) discovered that the influence of canal irrigation infrastructure to crop yield is non-existent in his study carried out in India. Estache, Speciale and Veredas (2005), on the other hand, posited the role of the water and sanitary infrastructure to be significant in fostering economic development in a study carried out in sub-Saharan nations.

However, in a study carried out by Kakar, Khilji and Khan (2011), a conclusion was reached that education correlates with development, which would significantly lessen income inequality. In addition, Afzal and Abbas (2010) approved that education has a significant impact on economic growth in Pakistan. Furthermore, Dauda (2009) scrutinized the effect of investments in educational sector on economic development in Nigeria and found a significant effect of expenditures in the educational sector on economic development. Bakare (2006) in his study discovered that a positive correlation exists between educational demand and economic growth. This means larger rate in school enrolments will result to economic development. A conclusion was therefore reached that the operative means to deal with illiteracy and foster economic development is via education. Hence, the sustainable development of the energy, education, water, and transportation system can serve as an instrument of change in any country.

The study concluded that the rising price of energy resources is a major barrier in the way of economic growth. Furthermore, from all energy resources, the impact of petroleum was seen to be critical for economic growth in Pakistan. Estache, Speciale and Veredas (2005), while analyzing importance of infrastructure regarding growth in sub-Sahara Africa, found positive effects between investments in education and economic development. In addition, Egert, Kozluk and Sutherland (2008) found that infrastructure enhanced economic development in OECD nations via augmentation of market competition and number of network externalities. A huge level of economic development was also equated to efficient investments in power and telecommunication sectors.

The utilitarian theory is the framework of theoretical analysis for this study. This theory rests on an ethical conundrum with significant bearing on utilitarianism. Bentham (2001) is the chief postulator of utilitarianism. He termed utility, as the sum total of all forms of gratification that is consequential of an action, devoid of torment to anyone involved in the action. Utilitarianism essentially considers all interests equally. Mill (2011) also made noteworthy additions to the theory of utilitarianism. In his view, utility denotes individuals carrying out actions for the purpose of social utility. This, to him denotes the comfort of people, and as such, an action that leads to the utmost pleasure for the members of the society.

Applying this theory to this study, it can be safely explained that the purpose of any government is to ensure the well-being of its citizens and the provision of adequate infrastructures would certainly go a long way in achieving this. The provision of an efficient power supply as opposed to a poor one would definitely improve the well-being of citizens. The availability of network of good roads would boost commercial activities significantly and reduce the occurrence of accidents. Higher economic growth level would result from healthy transport infrastructure, educational facilities, health system, energy system and other basic infrastructures in the society. The public investment on these infrastructures is vital to economic growth and development of a nation as this ensures the comfort of the people.

\section{Material and methods}

Ilorin is the state capital of Kwara State and is located on latitude $8^{\circ} 30^{\prime}$ and $8^{\circ} 50^{\prime} \mathrm{N}$ and longitude $4^{\circ} 20^{\prime}$ and $4^{\circ} 35 \mathrm{E}$. This study was carried out in Ilorin metropolis of Kwara State, Nigeria. Ilorin is home to diversity of culture, housing different ethnic groupings like Yoruba, 
Igbo, Hausa, Nupe, Baruba, etc. It is a home to Christians and Muslims. The study adopted a mixed method of design, utilizing a quantitative and qualitative technique of data collection. This was done so as to fuse the strengths of both techniques in gaining a deeper understanding of the people of Ilorin in terms of infrastructure and economic development. The respondents of the study were selected with the use of purposive sampling technique. This was based on the need to consult individuals who are properly acquainted with the infrastructural facilities, are mature and have spent at least a year in the study area. Based on this, 262 respondents were selected. From the selected respondents, ten individuals were selected for unstructured in-depth interview based on a show of interest. The analysis of the quantitative data was carried out with the use of chi square, with 250 questionnaires found to be valid. The qualitative data on the other hand was subjected to content analysis.

\section{Results}

Hypothesis One

$\mathrm{H} 0=$ There is no significant association between the state of rail transport system and the level of use by people of Ilorin Metropolis

Table 1. State of Rail Transport System and Level of Use by People of Ilorin Metropolis

\begin{tabular}{|l|l|l|l|l|}
\hline \multirow{2}{*}{$\begin{array}{l}\text { State of Rail Transport } \\
\text { System }\end{array}$} & Level of Use & Total \\
\cline { 2 - 4 } & Low & Moderate & High & \\
\hline Poor & 161 & 39 & 4 & 204 \\
\hline Fair & 7 & 30 & 1 & 38 \\
\hline Good & 3 & 0 & 0 & 3 \\
\hline Excellent & 2 & 1 & 2 & 5 \\
\hline Total & 173 & 70 & 7 & 250 \\
\hline
\end{tabular}

Source: Researchers' Fieldwork (2019) $\mathrm{C}^{2}(6, \mathrm{~N}=250)=85.214, \mathrm{p}=.001$.

The chi square value stands at 85.214. The degree of freedom is 6 with the significance level at .05 . Using these values, the chi-square table value is 12.59 . Since the $\chi^{2} \mathrm{c}$ is greater than the $\chi^{2} \mathrm{t}$, the alternate hypothesis is accepted and the null is rejected.

The result indicates a significant association between the state of the rail transport system and the level of use by people of Ilorin Metropolis. This connotes that the poorer the state of the road transport system, the lesser the use by people of Ilorin Metropolis.

Hypothesis Two

$\mathrm{H} 0=$ There is no significant association between the state of hydroelectric power supply and presence of industries in Ilorin metropolis

Table 2. State of Hydro-electric Power Supply and Presence of Industries

\begin{tabular}{|l|c|c|c|c|}
\hline \multirow{2}{*}{$\begin{array}{l}\text { State of Hydroelectric } \\
\text { Power Supply }\end{array}$} & \multicolumn{3}{|c|}{ Presence of Industries } & \multirow{2}{*}{ Total } \\
\cline { 2 - 4 } & Low & Moderate & High & \\
\hline Poor & 153 & 37 & 5 & 195 \\
\hline Fair & 14 & 30 & 0 & 44 \\
\hline Good & 1 & 3 & 2 & 6 \\
\hline Excellent & 2 & 0 & 3 & 5 \\
\hline Total & 170 & 70 & 10 & 250 \\
\hline
\end{tabular}

Source: Researchers' Fieldwork $(2019) \mathrm{C}^{2}(6, \mathrm{~N}=250)=102.865, \mathrm{p}=.001$. 
The chi square value stands at 102.865 . The degree of freedom is 6 with the significance level at .05 . Using these values, the chi-square table value is 12.59 . Since the $\chi^{2} \mathrm{c}$ is greater than the $\chi^{2} \mathrm{t}$, the alternate hypothesis is accepted and the null is rejected. This result indicates a positive association between the state of hydroelectric power supply and the presence of industries in Ilorin metropolis.

Hypothesis Three

$\mathrm{H} 0=$ There is no significant association between community educational level and gender equality in the employment of teachers in Ilorin metropolis

Table 3: Community Literacy Level and Level of Gender Equality in the Employment of Teachers

\begin{tabular}{|l|c|c|c|c|}
\hline \multirow{2}{*}{$\begin{array}{c}\text { Community Literacy } \\
\text { Level }\end{array}$} & \multicolumn{2}{|c|}{$\begin{array}{c}\text { Level of Gender Equality in the Employment of } \\
\text { Teachers }\end{array}$} & Total \\
\cline { 2 - 4 } & Low & Moderate & High & \\
\hline Low & 99 & 28 & 6 & 133 \\
\hline Moderate & 27 & 55 & 1 & 83 \\
\hline High & 4 & 21 & 9 & 34 \\
\hline Total & 130 & 104 & 16 & 250 \\
\hline
\end{tabular}

Source: Researchers' Fieldwork (2019) $\mathrm{C}^{2}(4, \mathrm{~N}=250)=84.112, \mathrm{p}=.001$.

The chi square value stands at 84.112. The degree of freedom is 4 with the significance level at .05 . Using these values, the chi-square table value is 9.49 . Since the $\chi^{2} \mathbf{c}$ is greater than the $\chi^{2} \mathbf{t}$, the alternate hypothesis is accepted and the null is rejected. The result indicates a significant association between community literacy level and level of gender equality.

\section{Interview Findings}

\section{Has the state of the rail transport system affected its level of use by people of Ilorin?}

The respondents in this study had similar views on how the state of the railway system affects its use by people of Ilorin metropolis. The following are some of the responses given by some of the respondents:

"Sure...The condition of the railway transport system is quite poor. It is outdated compared to what you can find in other countries. I do not use it that much. It is always hot in the train and quite congested. There was a time when the train got faulty while I was travelling. It was quite frustrating" (male, 31 years old).

Another respondent expressed a similar view:

"My brother, the train is not so good. It is very old and needs serious repair. There are no working fans in the train and it is always packed. I cannot take the train, especially in this heat. If it would be the modern type that is found in South Africa, America, then I will make use of the railway transport system very well" (female, 27 years old).

A respondent also had this to say on the question asked:

"The train is too slow. The train tracks are not properly maintained too. I do not take the train too much because of this. I only take it as a last resort. If these problems are fixed, I will start taking the train more" (male, 24 years old)

Another respondent had this to say:

"Although the train is bad, I still take it because it is cheaper than travelling by car. I only make fifteen thousand naira in a month so I have to find ways to cut down unnecessary costs. Despite this, I will be quite happy if the rail transport system can be upgraded to the modern standard" (female, 30 years old). 


\section{Does the state of the hydroelectric power supply affect the presence of industries in Ilorin metropolis?}

The respondents in this study had similar views on how the state of the hydroelectric power supply affects the presence of industries in Ilorin metropolis. The following are some of the responses given by some of the respondents:

"A lot of industries do not want to operate in Ilorin because of poor electricity. Most of them operate in Lagos or Abeokuta. Electricity in Ilorin is very poor. Even the industries that are in Ilorin do not depend on hydroelectric power supply. An industry serious about operating in Ilorin has to buy generators to survive" (male, 25 years old).

Another respondent expressed a similar view thus:

"The hydroelectric power supply in Ilorin is nothing to write home about. Since even the masses have to constantly use generators, industries have no choice. As this will be an additional cost, industries seldom settle in Ilorin. The electricity is so poor that we sometimes experience blackout for days" (female, 35 years old).

Another respondent's view is expressed thus:

"Industries operating in Ilorin have to find other sources of power as the hydroelectric power supply cannot be depended upon. It is epileptic in nature. Whenever rain falls, blackout follows, even if it is just a light drizzle. Such is the state of hydroelectric power supply in Ilorin. Because of this, industries might find it difficult to stay afloat in Ilorin" (male, 40 years old).

A respondent also expressed her view thus:

"It is not easy for industries to operate in Ilorin. The poor power supply is enough to chase them away as debt might be incurred if they remained. Not only is the hydroelectric power supply epileptic in nature, it is also exorbitant. If it is exorbitant for me, imagine the electricity bills that industries would have to pay" (female, 45 years old).

A respondent's view is also expressed thus:

"The period spent in blackout is longer than the time light is available. That shows just how poor the hydroelectric power supply is. Since even small scale businesses consider electricity to be a factor before starting up somewhere, then industries definitely consider it to before settling in a location" (female, 32 years old).

\section{Do you think community literacy level affects gender equality in the supply of teachers in} Ilorin metropolis?

The respondents in this study had similar views on if community literacy level affects gender equality in the supply of teachers in Ilorin metropolis. The following are some of the responses given by some of the respondents:

"A lot of people still believe that there is no point in females attending schools. I know a little girl that hawks instead of attending school. The girl's parents are not educated. How can a girl like that have a chance to be a teacher when she does not even attend school?" (female, 30 years old).

Another respondent's view is expressed thus:

"Ilorin is considered a city but there are some parts that are quite rural in nature. In such parts, girls are reminded that marriage is the most important aspect of their life. They do not aspire for much aside this. If you look at their parents, you will see that they are uneducated" (male, 27 years old).

Another respondent had this to say on the posed question:

"There are some jobs that are considered by people to be for men. Teaching is one of those. There are some schools where you cannot find a single female teacher. I believe that if the educational level of the general community is improved, then females stand a chance to penetrate not just teaching but other professions considered to be male-centred" (female, 40 years old). 
A respondent also had this to say on the question:

"If more members of the community get to go to school, especially the females, then they would be able to compete with males in terms of various professions that have been dominated by men for so long. I believe that the community educational level affects gender equality in the supply of teachers in Ilorin" (female, 32 years old)

\section{Discussions}

The figure below summarizes the assumptions of the study.

Figure 1. A Model Depicting the Relationship between the Tested Hypotheses

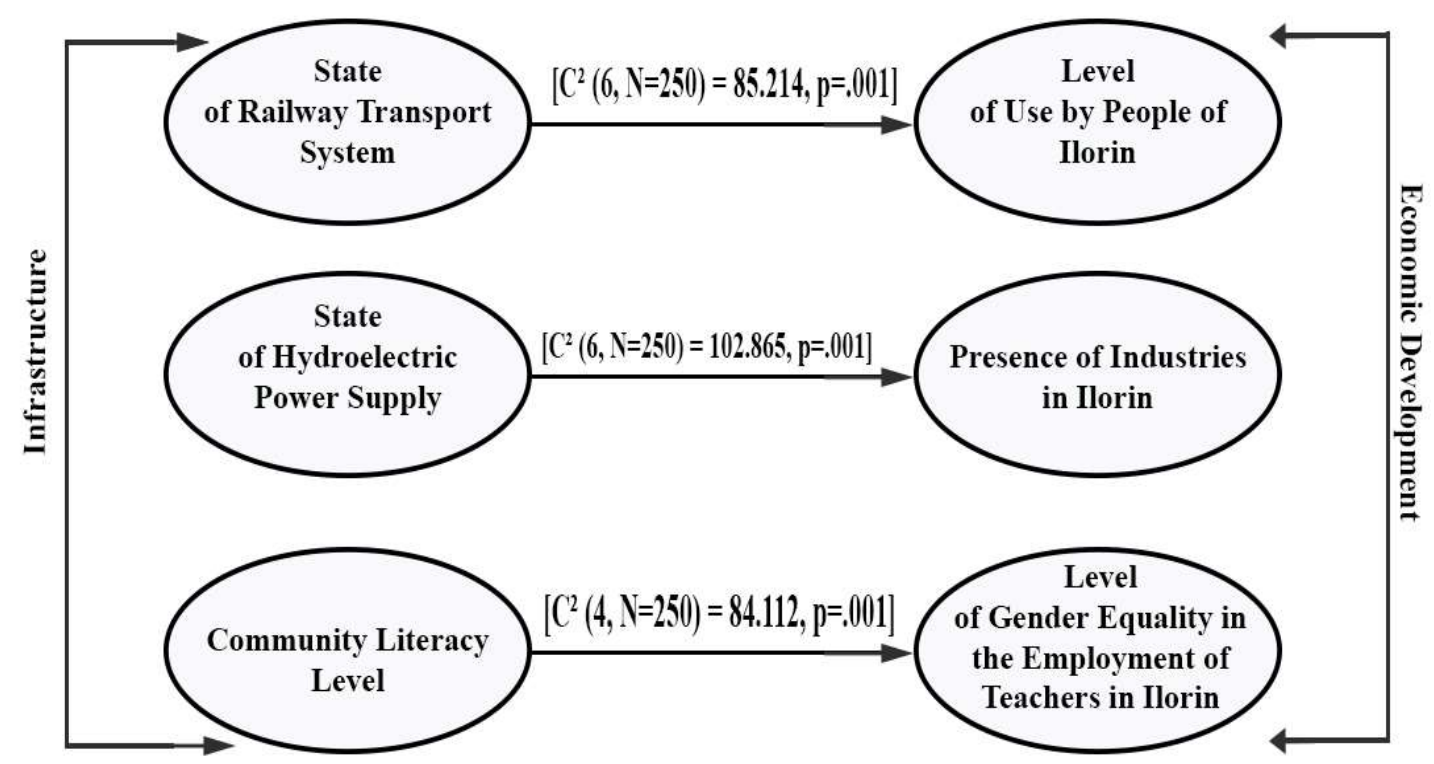

Source: Researchers’ Fieldwork (2019)

The provision of efficient and sufficient infrastructures to a certain extent serves not only in fostering economic development of Ilorin metropolis, but could as well boost the aesthetics of the city. The three hypotheses tested in this study revealed a positive association. The first hypothesis revealed a significant association between the state of rail transport system and level of use by people of Ilorin metropolis. As the state of railway transport system in Ilorin metropolis was described as poor by $81.6 \%$ of the respondents, the notion of the railway transport facilitating major economic development seems farfetched as it is scarcely used by the community. Thus, the availability of sufficient and efficient railway transport system can drive development of Ilorin metropolis. This is consistent with the findings of the study carried out by Fan and Chan-Kang (2005) on the impact of road investment in promoting production growth in China. Kuroda, Masahiro and Nangia (2007, p. 235-259) also revealed in a study that in the period between 7500-4000 BC, the Silk Road aided the exchange of goods between India, Mesopotamia and Chinese regions. Therefore, proper investment in the road/railway infrastructure could prove fortuitous for Ilorin metropolis. Not only would the government generate funds from a proper investment in the railway system, it would also facilitate trade 
activities among the masses, all contributing to developmental purposes in long run. To Rao (1968), the nexus between infrastructure and economic growth is a constant process through which economic development has to be led to achieve national and global stated objectives. Hence, a proper infrastructural system could be of critical relevance to a country. The availability of a well-functioning infrastructural system in terms of transports could prove to be very vital in matters of national defense. In addition, infrastructures could prove germane for developmental efforts. Infrastructures basically serve as drivers of social change. Advances in transport, industry, and education among others may very well alter the society for better. Although the critical relevance of sufficient infrastructural facilities has been well defined by the above findings, Ilorin metropolis still needs a lot in this area for sustainable development. There is no doubt that good roads, adequate power supply, and efficient educational system would make Ilorin a pride to other metropolis in Nigeria.

The second hypothesis revealed a significant association between the state of hydroelectric power supply and the presence of industries in Ilorin metropolis. Adequate electricity distribution would lead to increased production of goods and services which would concomitantly ensure a good business environment for the economic development of the metropolis. Industries are therefore finding it difficult to settle in Ilorin partly because of the epileptic power supply. The finding is related to the work of Ndebbio (2006) which cited that the supply of electricity drives the industrialization procedure. Similarly, in another work, Ukpong (1976) recognized the reality of a significant association between the consumption of electricity and economic development. This is similar to the findings of Siddiqui (2004) who revealed the benefits of energy resources, particularly petroleum in facilitating the growth of Pakistan's economy. Studies like Emeka (2008), Nnimmo (2007), and Odiaka (2006) have seen the growth in electricity supply as critical in quickening the advancement of the industrial sector. However, efficient energy system is still a mirage in Ilorin metropolis as the community is besieged with unstable and epileptic power supply. This perilous situation has grave implications for the running of industries, as most companies expended fortunes in generating their own power. This affects local and international businesses as it raises production costs in industries and discourages foreign investments, thereby constituting a major setback in the pursuit of economic development in the metropolis.

The third hypothesis also revealed a significant association between community literacy level and gender equality in the supply of teachers in Ilorin metropolis. As a scenario, the national budget indicated the relatively meagre funds set aside for education in Ilorin, which is a reflection of the country's investment in education, as can be seen in the budget for education in 2018 which is just 7.07 percent of the total budget (Punch, 2018). Gender equality is a necessity in terms of human capital. In a scenario where gender equality is the norm, meritocracy supersedes sexism. A study carried out by Amasuomo (2013) revealed that there was scarcity in the supply of female teachers in secondary schools in Bayelsa State, Nigeria. This is because a large portion of females do not attend schools as the parents believe that it interferes with prospects of marriage, which is seen as a priority. This view is supported by findings from the interview conducted in this study. Gender equality is one of the indicators of development as stated by Harbison and Myres (1964). According to Aja-Okorie (2013), it is becoming increasingly worrisome that efforts mustered by the Nigerian government to tackle gender disparity in education remain largely fruitless. Akinlo (2004) asserted that school enrolment serves as a significant contribution to human capital development. This is also in corroboration with findings of various researchers who have observed how expenditures on the educational sector influences economic development as indicated in the findings of Yogish (2006), and Permani (2009). Notwithstanding governmental investments in education, this study found out that the sector seems to be beclouded with problems. To some extent, a large proportion of schools in Ilorin are dominated by congestion, pitiable hygiene, poor administration, abysmal 
students-teachers' ratio, pitiable remunerations for teachers, abandoned capital projects, insufficient funding, pitiable conditions of service, etc. The ensuing effects of these multitudes of incongruities are the making of incompetent graduates and corruption of varying kinds among others. Thus, the appalling performance of the educational sector in Ilorin despite governmental expenditures on education has led to a poor level of social investments and this has stunted economic developmental efforts.

Harbison and Myres (1964) carried out a study of 75 countries with a focus on the correlation between GNP per capita enrollment in primary schools, between GNP per capita and enrollment in secondary schools and tertiary levels. A strong positive correlation was the result of this study. Curle (1964) has revealed a strong positive correlation between per capita income and enrollment in primary school as well. In addition, he indicated that a greater portion of a nation's wealth is intertwined with the funds made available for education. Estache, Speciale and Veredas (2005) in the analysis of sub-Sahara Africa also revealed the importance of education to economic development.

\section{Conclusions}

The study sought to shed more light on issues relating to infrastructure and economic development. From these findings, it is recommended that proper plans be made in making infrastructures available to the inhabitants of Ilorin metropolis. The railway system should be upgraded to meet modern standards as the findings reveal an outdated one. There should also be a great focus on improving electricity in the metropolis as it is a major driver of economic development. A stable power supply in the metropolis enhances the quality of the local business by ensuring productive employment among working age populace and also serves to draw in foreign investments. Attempts should be made to explore other sources of power such as solar if the provision of stable hydroelectricity proves to be a Herculean task. The educational infrastructure should as well be accorded the same level of importance. A sound educational system lays the blueprint for the quality of life lived by the habitants of the metropolis. It prepares them with the appropriate skills and abilities to use one's resources to contribute to the development of one's society. Therefore, the Kwara state government should invest more in education by upgrading the learning and teaching facilities in schools, ensure that there is gender equality in the enrollment of students in schools and employing competent teachers.

To ensure positive results from these plans and strategies, checks and balances should be in play to avoid possible cases of mismanagement of resources. There should be an air of transparency while carrying out these plans. Proper sensitization of members of the public on the utilization of infrastructural facilities would also be part of the indices of ensuring sustainable economic development. The public should be educated and encouraged on the maintenance of certain infrastructures. Finally, Kwara state government and other concerned agencies responsible for monitoring these infrastructural institutions should ensure continuity and consistency of the developmental policies.

\section{Bibliography}

1. Adenikinju, O.S., 2005. Analysis of the cost of infrastructure failure in a developing economy: The case of electricity sector in Nigeria, African Economic Research Consortium, 148, pp. 1-37.

2. Afzal, M. and Abbas, Q., 2010. Wagner's law in Pakistan: Another look, Journal of Economics and International Finance, 2(1), pp. 12-19.

3. Aja-Okorie, U., 2013. Women education in Nigeria: problems and implications for family role and stability. European Scientific Journal, 9(28), pp. 272-282. 
4. Akinlo, A.E., 2004. Foreign direct investment and growth in Nigeria: An empirical investigation. Journal of Policy Modelling, 26(5), pp. 627-639.

5. Amasuomo, J.O.M., 2013. Gender equality in teachers supply in secondary schools in Bayelsa State: implication for development. Journal of Education and Sociology, 4(2), pp. 119-122.

6. Anand, S. and Sen, A.K., 1994. Human development index: methodology and measurement, Readings in Human Development, pp. 138-151, Oxford University Press, New Delhi.

7. Aschauer, D.A., 2000. Public capital and economic growth: issues of quantity, finance and efficiency. Economic Development and Cultural Change, 48(2), pp. 391-406.

8. Bakare, A.S., 2006. The growth implication of human capital investment in Nigeria: An Empirical Study. Journal of Economics and Social Studies, 5(2), pp. 110-125.

9. Baldwin, J.R. and Dixon, J., 2008. Infrastructure Capital: What Is It? Where Is It? How Much of It Is There? Ottawa, Canada: The Canadian Productivity Review.

10. Bentham, J., 2001. The works of Jeremy Bentham. Published under the Superintendence of His Executor, John Bowring, Volume 1. Boston, USA: Adamant Media Corporation.

11. Binswanger H.P., Khandker, S.R. and Rosenzweig, M.R., 1993. How Infrastructure and Financial Institutions Affect Agricultural Output and Investment in India. Journal of Development Economics, pp. 41, 337-366.

12. Blakely, E.J., 1989. Planning Local Economic Development. Newbury Park, California: Sage Publications.

13. Camp, S.L. and Speidel, J., 1987. The International Human Suffering Index. Washington: Population Crisis Committee.

14. Chambers, R., 2004. Ideas for the Development: Reflecting Forwards. Brighton, England: Institute of Development Studies.

15. Chan, C., Forwood, D., Roper, H. and Sayers, C., 2009. Public Infrastructure Financing: An International Perspective. Australia: Productivity Commission Staff Working Paper.

16. Curle, A., 1964. Education, Politics and Development. Comparative Education Review, 7(3), pp. 226-245.

17. Dauda, R.O., 2009. Investment in education and economic growth in Nigeria: A Cointegration Approach. Paper Presented at the 9th Global Conference on Business and Economics held at University of Cambridge, UK.

18. Dethier, J., Hirn, M. and Straub, S., 2008. Explaining Enterprise Performance in Developing Countries with Business Climate Survey Data, Washington, DC: World Bank.

19. Diao, X. and Yanoma, Y., 2003. Exploring regional dynamics in Sub-Saharan African agriculture. Washington D.C., USA: International Food Policy Research Institute.

20. Edun, A.O., 2011. A Study of interactive effective of FDI on infrastructural development: Cement contribution in Nigeria (unpublished Ph.D. thesis). Wuhan University of Technology, China.

21. Egert, B., Kozluk, T. and Sutherland, D., 2008. Infrastructure and Growth: Empirical Evidence. OECD Economics Department Working Paper, Available from: $<$ https://econpapers.repec.org/paper/oececoaaa/685-en.htm>, [Accessed on 13 June 2019].

22. Emeka, E.O., 2008. Development Crisis of Power Supply and Implications for Industrial Sector in Nigeria. Stud Tribes Tribals, 6(2), pp. 83-92.

23. Estache, A., Speciale, B. and Veredas, D., 2005. How much does infrastructure matter to growth in Sub-Saharan Africa," European Center for Advanced Research in Economics Working Paper, Universite Libre de Bruxelles.

24. Estache, A. and Vagliasindi, M., 2007. Infrastructure for accelerated growth for Ghana: Needs and challenges, unpublished manuscript.

25. Fan, S. and Chan-Kang, C., 2005. Road Development, Economic Growth, and Poverty Reductionin China. Washington, DC, USA: IFPRI. 
26. Garsous, G., 2012. How Productive is Infrastructure? A Quantitative Survey. Université libre de Bruxelles: ECARES.

27. Gibson, J. and Rozelle, S., 2003. Poverty and Access to Roads in Papua New Guinea. Economic Development and Cultural Change, 52(1), pp. 159-185.

28. Gilbert, R., Stevenson, D., Girardet, H. and Stren, R., 1996. Making cities work: the role of local authorities in the urban environment, London: Earthscan.

29. Harbison, F. and Myres, C.A., 1964. Education, Manpower and Economic Growth, New York, Mc Graw Hill.

30. Henderson, H. 1994. Paths to sustainable development: The role of social indicators Futures 26(2), 125-137.

31. Hicks, N. and Streeten, P., 1979. Indicators of Development: The Search for a Basic Needs Yardstick. World Development, 7(6), pp. 567-580.

32. Kakar, Z.K., Khilji, B.A. and Khan, M.J., 2011. Relationship between education and economic growth in Pakistan: A Time Series Analysis. Journal of International Academic Research, 11(1), pp. 27-32.

33. Kuroda, H., Masahiro, K. and Nangia, R., 2007. Infrastructure and Regional Cooperation. In Bourguignon, F. and Pleskovic, B. (eds) Global: Rethinking Infrastructure for Development Washington D.C., Annual World Bank Conference on Development Economics.

34. Mill, J.S., 2011. A system of Logic, Ratiocinative and Inductive (Classic Reprint). USA: Forgotten Books.

35. Ndebbio, J., 2006. The structural economic dimensions of underdevelopment, associated vicissitudes and imperatives: agenda for positive change', 33rd Inaugural Lecture, University of calabar-Nigeria, saesprint publishers-Nigeria.

36. Nnimmo, B., 2007. Gender and Energy Crisis in Developing Economies. USA: Community Research and Development Centre.

37. Odiaka, P., 2006, August 24. Power Sector Reforms: Still a reign of Blackout, The Guardian, pp. 15.

38. Permani, R., 2009. The role of education in economic growth in East Asia: A Survey. AsianPacific Economic Literature, 23(1), pp. 1-20.

39. Punch, 2018, June 20. 2018 Budget and the Paltry Allocation for Education. Available from: $<$ https://punchng.com/2018-budget-and-the-paltry-allocation-for-education/>. [Accessed on 9 June 2018].

40. Rao, V.K.R.V., 1968. Investment Income and Multiplies in an under Developed Economy. In Agarwala A.N. and Singh S.P. (Ed) 'The Economics of Underdevelopment' Oxford University Press, Bombay.

41. Rada, C., 2013. Valori identitare ale familiei româneşti contemporane în contextul globalizării. $O$ abordare antropologică, (Identitary Values of the Contemporary Romanian Family in the Framework of the Globalization. An Anthropological Approach) p.336. Bucureşti: Editura Muzeului Naţional al Literaturii Române, Colecția AULA MAGNA. Available from: <http://www.cultura.postdoc.acad.ro/cursanti/sinteze/rada_cornelia.pdf $>$. [Accessed on 9 June 2018].

42. Siddiqui, R., 2004. Energy and Economic Growth in Pakistan. The Pakistan Development Review, 43(2), pp. 175-200.

43. Shah, N., 1969. Infrastructure for Indian Economy. Bombay: University Press.

44. Uwagboe, F. 2011. Infrastructural Development and Economic Growth in Nigeria. MSc Thesis, Unpublished. Benin City: University of Benin.

45. Ukpong, I.I., 1976. An Analysis of the causes of power shortage in Nigeria. The Nigerian Journal of Economic and Social Studies.18, pp. 34-49.

46. Van der Gaag, J., 2011. The economics of human development. Presented at the 2011 International Conference on Early Childhood Development, Beijing. Available from: 
$<$ https://www.brookings.edu/on-the-record/the-economics-of-human-development/>. [Accessed on 14 June 2019].

47. Yogish, S.N., 2006. Education and economic development. Indian Journal of Social Development, 6(2), 255-270. 